\title{
APLIKASI DINSAR UNTUK IDENTIFIKASI DEFORMASI PERMUKAAN GUNUNG ANAK KRAKATAU PADA PERISTIWA LONGSOR SEBELUM TSUNAMI SELAT SUNDA
}

\author{
I Gede Boy Darmawan*, Zelica Krismalia Marsauli Manurung, Muhammad Nurul, Winona Putri Prihadita, \\ Karyanto \\ Program Studi Tenik Geofisika, Fakultas Teknik, Universitas Lampung \\ *Penulis Korespondensi : igedeboy@staff.unila.ac.id
}

\begin{abstract}
Abstrak. Tsunami Selat Sunda yang terjadi pada akhir tahun 2018 akibat deformasi (longsor) Gunung Anak Krakatau (GAK) tidak memiliki Early Warning System (EWS) yang memadai bahkan tidak terdeteksi oleh seismogram dengan jelas. Peristiwa itu menunjukkan bahwa pemantauan deformasi GAK sangat diperlukan. Penelitian ini bertujuan untuk mengetahui proses deformasi GAK sebelum tsunami menggunakan metode DInSAR. Metode ini memanfaatkan perbedaan dua fase atau lebih citra SAR dengan akuisisi yang berbeda untuk memperoleh topografi dan deformasi. Data yang digunakan adalah sepasang citra Sentinel-1 yang diakuisisi pada periode 7-19 Desember 2018. Penelitian ini berhasil menunjukkan GAK telah mengalami deformasi beberapa hari sebelum tsunami Selat Sunda pada 22 Desember 2018 terjadi. Nilai deformasi GAK pada periode ini sebesar -0.12 sampai 0.04 meter relatif terhadap Line of Sight (LOS). Hasil tersebut menunjukkan deformasi yang terjadi mencakup 94 Ha luas area GAK dengan $\pm 32,036 \mathrm{~m}^{3}$ material vulkanik yang bergerak dominan ke arah barat daya. Volume material yang cukup banyak ini tidak menghasilkan tsunami, diperkirakan karena periode pergerakan tersebut terjadi secara perlahan/tidak seketika yaitu pada rentang 12 hari. Material longsoran tertumpuk dan menjadi tidak stabil, kemudian terjadi longsoran serentak yang kemungkinan dipicu oleh banyaknya aktivitas vulkanik GAK akhirnya memicu terjadinya tsunami pada 22 Desember 2018. Temuan ini menunjukkan bahwa citra SAR mampu mengidentifikasi adanya pergerakan massa pada lereng GAK sebelum tsunami terjadi, sehingga dapat digunakan untuk monitoring permukaan GAK sebagai sistem peringatan dini pada deformasi yang berpotensi menyebabkan tsunami di kemudian hari.
\end{abstract}

Kata Kunci: citra SAR; deformasi; DInSAR; Krakatau; tsunami

Abstract. The Sunda Strait Tsunami that occurred at the end of 2018 due to the deformation (landslide) of Gunung Anak Krakatau (GAK) volcano did not have an adequate Early Warning System (EWS) that was not even detected by the seismogram clearly. The incident shows that monitoring of GAK deformation is very much needed. This study aims to determine the GAK deformation process before the tsunami using the DInSAR method. This method utilizes two or more phases of SAR images with different acquisitions to obtain topography and deformation. The data used is a pair of Sentinel-1 images acquired in the period 7-19 December 2018. This research successfully showed that GAK had been deformed several days before the Sunda Strait tsunami on 22 December 2018. In this period, the deformation value of GAK is -0.12 to 0.04 meters relative to the Line of Sight (LOS). The result shows that the deformation covering 94 hectares of GAK area with $\pm 32.036 \mathrm{~m}^{3}$ of volcanic material moves predominantly towards the Southwest. This large volume of material does not produce a tsunami, and it is estimated that the period of movement occurs slowly / not instantaneously, namely in 12 days. The landslide material accumulated and became unstable, and then a simultaneous landslide occurred, which was probably triggered by a lot of GAK volcanic activity, which finally triggered a tsunami on December 22, 2018. This finding shows that the SAR image can identify mass movement on the GAK slopes before the tsunami occurs, so it can be used for monitoring the surface of the GAK as an early warning system for deformations that have the potential to cause a tsunami in the future.

Keywords: SAR images; deformation; DInSAR; Krakatau; tsunami

\section{PENDAHULUAN}

Potensi terjadinya tsunami akibat aktivitas vulkanisme Gunung Anak Krakatau (GAK) di Selat Sunda (Gambar 1) telah lama diteliti. Mulai dari memodelkan struktur GAK dari data gravitasi dan batimetri hingga menemukan adanya kaldera dengan kedalaman $240 \mathrm{~m}$ serta dinding kaldera curam dan berpotensi untuk runtuh (Deplus dkk., 
1995), hingga membuat kajian potensi tsunami di Selat Sunda akibat longsoran bawah laut (Yudhicara dan Budiono, 2014). Model numerik potensi tsunami yang berkaitan dengan runtuhan dinding kaldera Krakatau termasuk pola sebaran tinggi gelombang tsunami yang sampai di pesisir Kalianda dan Banten juga telah dilakukan (Giachetti dkk., 2012). Model tsunami tersebut diperkuat oleh penelitian lainnya yang menyebutkan bahwa tsunami dapat terjadi akibat aktivitas vulkanisme yang meningkat hingga runtuhnya dinding GAK (Paris dkk., 2014).

Penelitian tersebut terbukti dengan terjadinya peristiwa tsunami di Selat Sunda pada tanggal 22 Desember 2018 yang menewaskan lebih dari 400 orang dan lebih dari 7000 orang terluka (Fauzi dkk., 2020; Solihuddin dkk., 2020). Kejadian ini merupakan pukulan telak dalam upaya mitigasi bencana di Kawasan Selat Sunda. Salah satu penyebab banyaknya korban dalam peristiwa ini adalah ketidaksiapsiagaan masyarakat. Ketidaksiapsiagaan ini setidaknya dipicu oleh kurangnya peringatan dini tsunami sebelum gelombang tsunami mencapai kawasan pantai. Menurut BMKG (2018), hal ini diakibatkan oleh sensor seismograf pada sistem pendeteksi gempa di wilayah Banten dan Lampung tidak memproses secara otomatis karena getaran yang tercatat bukan sinyal gempa tektonik. Sensor tide gauge yang tersebar di kawasan pantai Selat Sunda juga tidak mampu memprediksi kedatangan gelombang sebelum tsunami terjadi.
Berbagai survei terkait kondisi pasca-tsunami telah dilakukan untuk melihat proses penjalaran gelombang tsunami Selat Sunda. Hasil survei menunjukkan gelombang tertinggi mencapai 13 meter dengan jarak inundasi terjauh yaitu 330 meter dari pantai (Muhari dkk., 2019; Putra dkk., 2020). Kecepatan gelombang tsunami mencapai $4,37 \mathrm{~m} / \mathrm{s}$ yang disimpulkan dari adanya besarnya batuan berukuran boulder di Banten (Syamsidik dkk., 2020). Berdasarkan data SAR, diprediksi bahwa penyebab tsunami adalah adanya longsoran di bagian tenggara dari lereng GAK seluas kurang lebih $0,2 \mathrm{~km}^{2}$ (Ye dkk., 2020).

Rekonstruksi peristiwa tsunami Selat Sunda akibat runtuhnya lereng GAK menunjukkan bahwa longsoran yang memicu tsunami tidak besar, bahkan 8 jam setelah tsunami, puncak GAK masih tampak utuh, meskipun kemudian puncak tersebut hancur yang diperkirakan akibat dari erupsi lereng setelah tsunami (Williams dkk., 2019). Temuan ini menjadi perhatian penting mengingat besarnya gelombang tsunami yang dihasilkan dari longsoran vulkanik volume kecil ini. Oleh karena itu, penting untuk membangun sistem peringatan dini yang mampu mendeteksi pergerakan massa ini.

Kompleksnya mekanisme peristiwa tsunami Selat Sunda menjadi perhatian dan pelajaran penting di kemudian hari. Permasalahan yang belum bisa dipastikan hingga kini yakni apakah peristiwa longsoran pada lereng GAK yang memicu tsunami

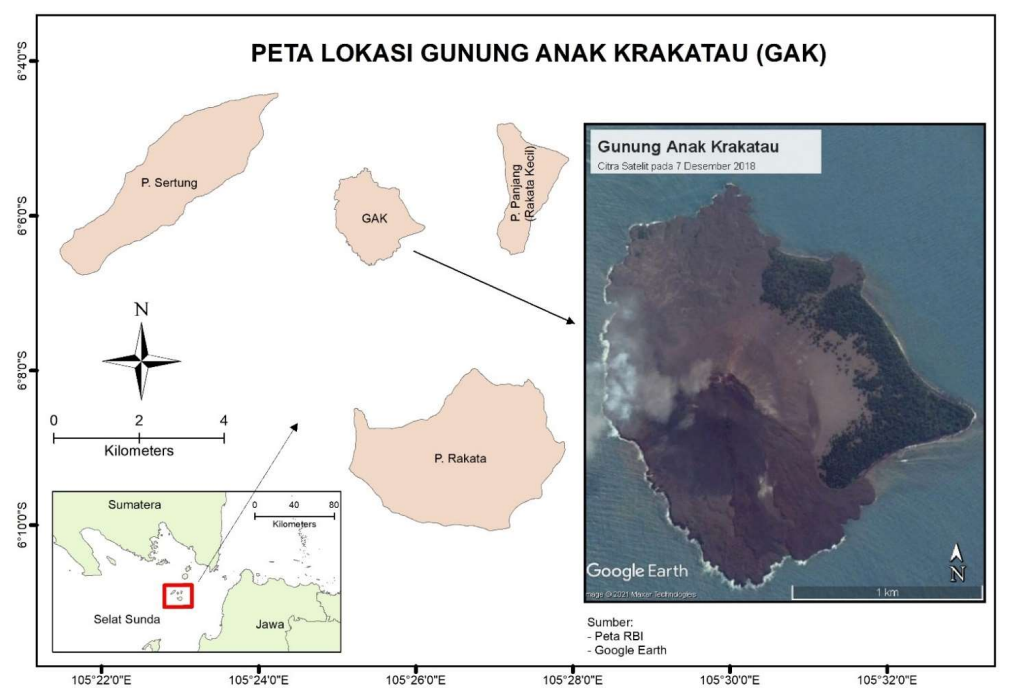

Gambar 1. Peta lokasi penelitian di Gunung Anak Krakatau (GAK) yang menunjukkan kondisi citra satelit sebelum longsor dan tsunami Selat Sunda 
disebabkan oleh aktivitas vulkanik atau aktivitas seismik. Berdasarkan hasil perbandingan antara data seismik yang diperoleh pada tahun 2017 dan 2019 memberikan gambaran tentang proses emplasemen longsor, urutan endapan, dan struktur di bawah permukaan laut. Temuan ini menyimpulkan bahwa area run out tanah longsor baratdaya dari keruntuhan GAK kurang lebih $7,02 \mathrm{~km}^{2}$ (Priyanto dkk., 2021).

Karena peristiwa tsunami akibat longsoran lereng GAK merupakan peristiwa langka, maka sangat penting menghasilkan informasi tentang proses prekursor dan bantuan untuk menyempurnakan teknologi pemantauan dan peringatan dini yang ada. Oleh karena itu, sistem peringatan dini tsunami generasi mendatang harus mempertimbangkan pengamatan multiparametrik, karena hasil penelitian mengungkapkan bahwa banyak perubahan yang menandakan tingkat aktivitas yang belum pernah terjadi sebelumnya di GAK sebelum 22 Desember 2018 (Walter dkk., 2019).

Berdasarkan pada berbagai temuan dan saran dari berbagai referensi sebelumnya, penelitian ini akan fokus pada proses identifikasi deformasi permukaan GAK pada peristiwa longsor sebelum tsunami selat sunda terjadi. Penelitian ini memanfaatkan sepasang citra Sentinel-1 dengan mode akuisisi Ascending untuk melihat deformasi GAK dari arah baratdaya. Pengukuran gerakan massa pra-tsunami menggunakan metode DInSAR dilakukan untuk menghitung besar dan luasnya gerakan massa di permukaan GAK. Hasil DInSAR juga digunakan untuk menghitung volume gerakan massa pra-tsunami untuk mengidentifikasi pemicu tsunami Selat Sunda.

\section{Geologi Gunung Anak Krakatau}

Stratigrafi Krakatau dibagi menjadi 4 produk letusan dari tua sampai muda (Gambar 2): 1) Krakatau pra-sejarah; produk ini meletus sekitar tahun 416 AD dan terdiri dari 2 dacitic lava lows, 1 pyroclastic flow dan 1 pyroclastic fall; 2) Krakatau muda; produk-produk ini meletus sekitar tahun 1200 $\mathrm{M}$ dan terdiri dari 3 pusat letusan: Rakata, Danan, dan Parbuwatan. Selama periode ini, produk didominasi oleh lava; 3) periode penghancuran gunung berapi Rakata, Danan, dan Parbuwatan, ditandai oleh pembentukan kaldera 1883, dan menghasilkan produk letusan yang unik. Unit batu ini didistribusikan di ketiga pulau Rakata, Panjang dan Sertung yang terdiri dari pumice pyroclastic flows, minor pyroclastic falls dan surge deposits; 4) Anak Krakatau; sejak kelahirannya pada tahun 1927 hingga 2017, Anak Krakatau telah meletus setidaknya tiga puluh dua kali, menunjukkan kombinasi kegiatan eksplosif dan efusif.

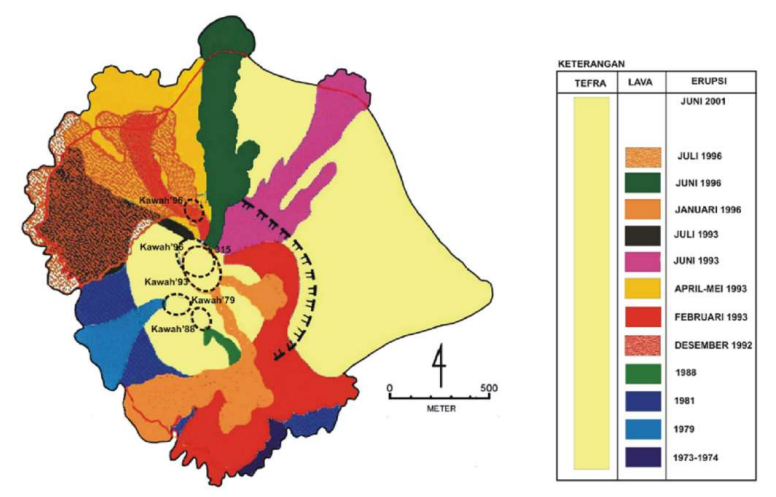

Gambar 2. Peta Geologi Gunung Api Anak Krakatau, Lampung Selatan (Sutawidjaja, 2006)

Gunung Anak Krakatau, dengan ketinggian sekitar $300 \mathrm{~m}$ di atas permukaan laut, adalah sebuah pulau gunung berapi, tergeletak di pusat vulkanik Kompleks Krakatau (Gambar 2). Hal ini dibangun dari lapisan bolak-balik dari 18 aliran lava dan 18 endapan piroklastik yang telah dibangun sejak tahun 1927 (Abdurrachman dkk., 2018). Daerah vulkanik krakatau terletak dari Jalur Tektonik Jawa dengan jarak $140 \mathrm{~km}$ dimana di bawah terdapat wilayah penunjaman pada kedalaman $120 \mathrm{~km}$ (Zen dan Sudradjat, 1983). Effendi dkk. (1983) berpendapat bahwa daerah vulkanik Krakatau dipengaruhi oleh pergerakan tektonik dari sistem Sesar Sumatra Selatan, struktur tersebut ditandai oleh keberadaan dike dan rekahan di Pulau Rakata dan struktur seperti graben di Anak Krakatau. Gunung Anak Krakatau berada di kawasan Kaldera Krakatau dimana terbentuk saat letusan paroksimal kedua tahun 1883. Geomorfologi daerah vulkanik Gunung Anak Krakatau tersusun atas dataran, dinding kaldera, aliran lava, bentukan kerucut vulkanik, dan pesisir. Kenampakan dinding yang sangat curam di Pulau Rakata khususnya di bagian utara mencirikan 
morfologi kaldera dengan bentuk cekung dan menghadap ke arah utara.

\section{Differential Interferometry Synthetic Aperture Radar (DInSAR)}

DInSAR merupakan singkatan dari Differential Interferometry Synthetic Aperture Radar adalah metode pencitraan radar kesamping/side looking dengan menggunakan informasi fase, panjang gelombang, dan amplitudo (Firdaus dkk., 2016). Metode DInSAR mengolah data InSAR dengan cara mendeferensialkan data citra SAR (Persamaan 1-4).

$\Delta \varphi_{\text {Int }}=\varphi_{S}-\varphi_{M}$

$\Delta \varphi_{\text {Int }}=\frac{\Delta R_{S-M}+\Delta R_{S^{\prime}-S}}{\frac{\lambda}{4 \pi}}+\varphi_{\text {scatt }-S}-\varphi_{\text {scatt }}$

dengan:

$\Delta \varphi_{\text {Int }}:$ perbedaan fase InSAR dari fase citra Slave $\left(\varphi_{S}\right)$ dan Master $\left(\varphi_{M}\right)$

$\Delta R_{S-M}$ : perbedaan jarak satelit dengan titik permukaan $\mathrm{P}$ (Gambar 3) pada citra Slave (S) dan Master (M)

$\Delta R_{S^{\prime}-S}$ : perubahan permukaan (deformasi) diukur dari perbedaan jarak citra Slave ke titik P dan $\mathrm{P}^{\prime}$ atau jarak d pada Gambar 3

$\lambda$ : panjang gelombang radar dengan pergeseran fase selama interaksi antara gelombang radar (baik Master maupun Slave) dengan permukaan ( $\left.\varphi_{\text {scatt }}\right)$

$\Delta \varphi_{D-\text { Int }}=\Delta \varphi_{\text {Int }}-\varphi_{\text {Topo_flat }_{\text {fla }}}=\varphi_{D}$

$\Delta \varphi_{D-I n t}=\varphi_{D}+\varphi_{\text {Topo }_{\text {res }}}+\Delta \varphi_{\text {Atm }}+\Delta \varphi_{\text {orb }}+$

$\varphi_{\text {Noise }}+2 k \pi$

dengan:

$\Delta \varphi_{D-\text { Int }} \quad$ : nilai fase deformasi total (DInSAR)

$\varphi_{\text {Topo_flat }}$ : fase topografi bumi datar

$\varphi_{\text {Topo }_{\text {res }}}$ : residual error topografi

$\Delta \varphi_{\text {Atm }} \quad$ : fase error akibat pengaruh atmosfer

$\Delta \varphi_{\text {orb }} \quad$ : fase error akibat pengaruh orbit

$\varphi_{\text {Noise }} \quad$ : fase noise

$2 k \pi \quad$ : fase ambiguitas

$\varphi_{D} \quad$ : fase deformasi permukaan

Metode DInSAR mampu mendeteksi perubahan permukaan topografi dengan ketelitian tinggi dengan memanfaatkan pasangan interferogram dari citra SAR (Aji dkk., 2018). Data citra SAR menggunakan penggabungan kompleks di posisi spasial yang sama (differential SAR) maupun posisinya berbeda (terrain height InSAR) di area sama dengan melakukan perkalian konjugasi berganda. Target dapat berupa model elevasi digital (DEM) maupun peta deformasi permukaan bumi (Pratiwi dkk., 2017).

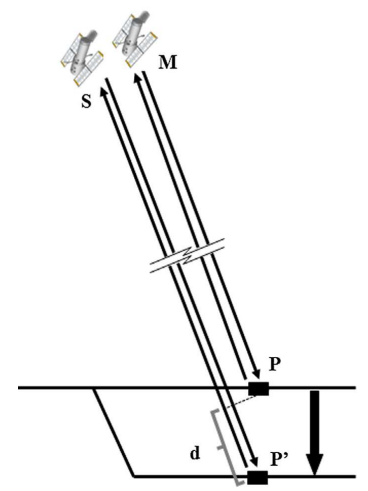

Gambar 3. Skema pengukuran DInSAR menggunakan sepasang citra SAR sebagai Master dan Slave

(Crosetto dkk., 2016)

Sentinel-1A merupakan sebuah satelit pencitraan radar dari European Space Agency (ESA) yang menjadi bagian dari program Copernicus Uni Eropa. Sentinel-1 terdiri dari dua satelit yang mengorbit secara berdampingan dengan jarak sejauh $180^{\circ}$ yaitu Sentinel-1A dan Sentinel-1B dengan sensor C-band (Islam dkk., 2017). Satelit ini membawa Radar Aperture C-band dengan frekuensi $5,405 \mathrm{GHz}$ dan melakukan pencitraan pada daerah yang sama dengan selang waktu 12 hari di ketinggian orbit $693 \mathrm{~km}$ dan pada inklinasi $98,18^{\circ}$. Satelit ini dapat melacak dalam segala aspek lingkungan, mulai dari mendeteksi dan melacak tumpahan minyak, pemetaan es laut, pemetaan perubahan cara penggunaan lahan, serta perubahan deformasi tanah (Cyntia, 2018). Citra Sentinel-1 memiliki empat teknik akuisisi yakni Interferometric Wide Swath (IW), Stripmap (SM), Wave (WV), dan Extra Wide Swath (EW). Mode Interferometric Wide Swath citra satelit Sentinel-1A mempunyai resolusi spasial $5 \mathrm{~m} \times$ 20 m (Nurtyawan dan Utami, 2020).

Penelitian serupa dilakukan oleh Febriyanti dan Anjasmara (2017) dengan menganalisis deformasi Gunung Raung menggunakan teknologi DInSAR. Penelitian ini mempergunakan metode DInSAR teknik two pass dan three pass. Data yang digunakan adalah citra satelit Sentinel-1A yang diakuisisi pada Juni, Juli, dan September 2015 serta Digital Elevation 
Model SRTM 30 meter. Penggunaan dua metode memiliki tujuan untuk membandingkan hasil pengolahan dari kedua metode tersebut jika diterapkan bersamaan apakah memiliki hasil yang sama atau berbeda. Hasil didapatkan bahwa metode DInSAR two pass dan three pass dapat mendeteksi deformasi yang terdapat kaldera Gunung Raung. Sehingga ditarik kesimpulan bahwa metode DInSAR dapat digunakan untuk mengetahui nilai deformasi di permukaan Gunung Raung.

\section{METODOLOGI}

Metode penelitian yang digunakan pada penelitian ini berfokus pada pemanfaatan Citra Sentinel-1 untuk mengidentifikasi deformasi GAK sebelum tsunami Selat Sunda. Data Sentinel-1 diakses dari https://www.asf.alaska.edu/ periode akuisisi Desember 2018. Metadata lengkap dari data Sentinel-1 yang digunakan pada penelitian ini disajikan pada Tabel 1 di bawah ini.

Tabel 1 Metadata Sentinel-1 yang digunakan dalam pengolahan DInSAR GAK

\begin{tabular}{|c|c|c|}
\hline $\begin{array}{l}\text { Meta- } \\
\text { data }\end{array}$ & Master & Slave \\
\hline Nama & S1A_IW_SLC_1SD & S1A_IW_SLC_1SD \\
\hline Produk & V_20181207T11230 & V_20181219T1123 \\
\hline & 7_20181207T11233 & 06_20181219T112 \\
\hline & 7_024918_02BEB6_ & 336_025093_02C5 \\
\hline & $\mathrm{B} 27 \mathrm{C}$ & OF_1740 \\
\hline $\begin{array}{l}\text { Waktu } \\
\text { Akuisisi }\end{array}$ & $7-12-2018$ & $19-12-1018$ \\
\hline Mode & \multicolumn{2}{|c|}{ Ascending } \\
\hline Swath & \multicolumn{2}{|c|}{ IW3 } \\
\hline $\begin{array}{c}\text { Prep. } \\
\text { Baseline }\end{array}$ & \multicolumn{2}{|c|}{$112 \mathrm{~m}$} \\
\hline $\begin{array}{c}\text { Temp. } \\
\text { Baseline }\end{array}$ & \multicolumn{2}{|c|}{11 hari } \\
\hline
\end{tabular}

Seluruh tahapan pengolahan data Sentinel-1 pada penelitian ini dilakukan dengan menggunakan software SNAP dan SNAPHU. Tahapan pertama adalah mengasilkan interferogram dengan metode InSAR. Setelah interferogram terbentuk, tahap berikutnya dilakukan dengan mentransformasikan nilai fringes dari interferogram yang mengindikasikan perbedaan fase gelombang agar menjadi nilai deformasi. Teknik yang digunakan adalah DInSAR atau Differential Interferometry SAR menggunakan perangkat lunak SNAPHU pada tahapan Phase Unwrapping yang menerapkan algoritma Minimum Cost Flow (MCF) dan konfigurasi DEFO. Langkah-langkah dalam tahapan pengolahan data pada penelitian ini ditunjukkan oleh Gambar 4.

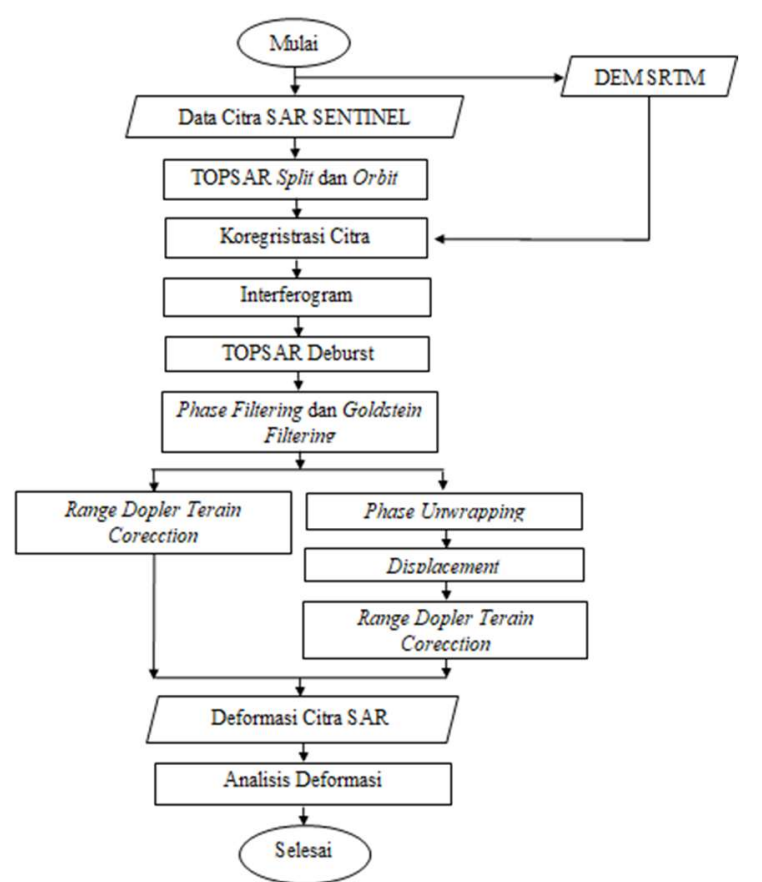

Gambar 4. Diagram alir pengolahan DInSAR pada penelitian ini

\section{Interferogram dan Koherensi}

Tahap interferogram generation menghasilkan deformasi dalam satuan radian (satuan sudut fase) dalam rentang $-\pi$ sampai dengan $\pi$. Nilai ini akan menimbulkan ambiguitas jika deformasi melebihi rentang tersebut. Pada fase interferogram didapatkan fringes yang terbentuk akibat orbit yang tidak sama persis dengan saat pengambilan citra SAR. Fringes yang terbentuk pada interferogram berbentuk garis tipis yang menggambarkan besar fase di nilai yang sama. Besar phase diperoleh dari penjalaran gelombang elektromagnetik melalui media atmosfer dari sensor satelit ke objek. Perlambatan atau percepatan gelombang elektromagnetik di atmosfer juga akan mempengaruhi fringes yang ada di interferogram. Tahap pembentukan interferogram diperoleh dari dua citra SAR (master dan slave) yang diambil pada 
daerah yang sama di waktu yang berbeda. Nilai pada beda fase akan menampilkan adanya ground movement (Kurniawan dan Anjasmara, 2016).

Interferogram yang dihasilkan pada proses InSAR akan memiliki bermacam nilai koherensi yang berbeda. Koherensi merupakan nilai yang digunakan untuk mengestimasi phase noise dari citra interferogram dengan kisaran nilai antara 0 sampai 1. Nilai 1 menggambarkan koherensi yang paling tinggi yang berarti pasangan citra identik dan memiliki informasi yang akurat berdasarkan kualitas pada citra interferogram, sedangkan koherensi dengan nilai 0 berarti tidak ada kesamaan sama sekali. Umumnya pada pemanfaatan teknik InSAR, minimal nilai koherensi yang baik yaitu 0,4 . Tujuan koherensi adalah menentukan kualitas pengukuran (misalnya phase interferometry). Nilai koherensi kurang dari 0,4 menyebabkan nilai Fasanya tidak layak atau sebaiknya tidak digunakan dalam proses berikutnya (Ckhotimah dkk., 2020).

\section{Phase Filtering dan Phase Unwrapping}

Proses phase filtering dilakukan untuk meningkatkan nilai Signal to Noise Ratio (SNR) pada interferogram karena pengaruh dari penjalaran sinyal kembali yang melewati medium udara atau atmosfer. Filtering digunakan untuk mengurangi efek dari noise dan orbit yang dapat menurunkan kualitas citra SAR. Proses ini dapat meningkatkan nilai akurasi serta mempertajam fase pada daerah dengan nilai koherensi yang masih cukup besar (Monterroso dkk., 2018). Proses ini bertujuan untuk menghilangkan speckle dapat muncul di interferogram. Proses ini berguna dalam melakukan filter pada interferogram. Penelitian Goldstein dan Werner (1998) berhasil membuktikan terjadinya peningkatan signifikan pada visibilitas fringes setelah melakukan proses filtering pada interferogram.

Tahap selanjutnya adalah Phase Unwrapping yang dilakukan dengan bantuan software SNAPHU v.2.0.4. Pada tahapan ini, dilakukan proses Differential InSAR (DInSAR) dengan memilih konfigurasi DEFO pada SNAPHU. Proses ini memerlukan koreksi medan (terrain correction) guna menghilangkan/mereduksi efek topografi. Model topografi yang digunakan pada tahapan ini sama dengan data elevasi yang digunakan saat proses Koregistrasi Citra, yaitu DEM SRTM. Citra hasil dari proses DInSAR ini masih dalam satuan radian (satuan sudut fasa) dalam rentang $-2 \pi$ sampai dengan $2 \pi$. Setelah melakukan proses unwrapping pada citra interferogram akan diperoleh nilai deformasi dalam fase absolut dan diubah ke satuan metrik dengan algoritma Displacement pada SNAP. Tahapan terakhir dilakukan konversi koordinat slant range ke koordinat kartografik hingga diketahui letak dan posisi lokasi di permukaan bumi sehingga memudahkan dalam interpretasi sebaran nilai deformasi.

Setelah melewati seluruh proses pengolahan DInSAR, maka diperoleh nilai hasil deformasi dalam satuan meter. Hasil ini kemudian difilter kembali menggunakan proses masking untuk menghilangkan efek deformasi permukaan selain akibat pergerakan massa, misalnya efek vegetasi. Setelah diperoleh area deformasi, luasan area dapat dihitung dengan mengkalikan jumlah piksel dengan resolusi piksel.

$D_{v}=\left(D_{N} \times R_{N}\right) \times D_{h}$

dengan:

$D_{v} \quad$ : volume deformasi relatif terhadap LOS $\left(\mathrm{m}^{3}\right)$

$D_{N} \quad$ : jumlah piksel deformasi

$R_{N} \quad$ : resolusi piksel deformasi (m2)

$D_{h} \quad$ : tinggi deformasi tiap piksel relatif terhadap $\operatorname{LOS}(\mathrm{m})$

Sedangkan untuk menghitung volume massa yang bergerak dilakukan dengan perkalian luas area deformasi dengan tinggi deformasi hasil DInSAR seperti yang ditunjukkan pada persamaan 5 (relatif terhadap Line of Sight / LOS).

\section{HASIL DAN PEMBAHASAN}

Berdasarkan hasil pengolahan data DInSAR pada penelitian ini, diperoleh sebaran nilai koherensi yang bervariasi pada rentang $0,18-0,78$ dan ratarata berada pada nilai 0,48 (Gambar 5a). Hasil ini cukup baik mengingat aktivitas erupsi vulkanik yang cukup tinggi pada periode Desember 2018 di GAK. Nilai koherensi yang cukup rendah di bagian timur ke arah tenggara GAK merupakan efek vegetasi. Kerapatan vegetasi akan mempengaruhi nilai koherensi citra karena mengganggu pemantulan 

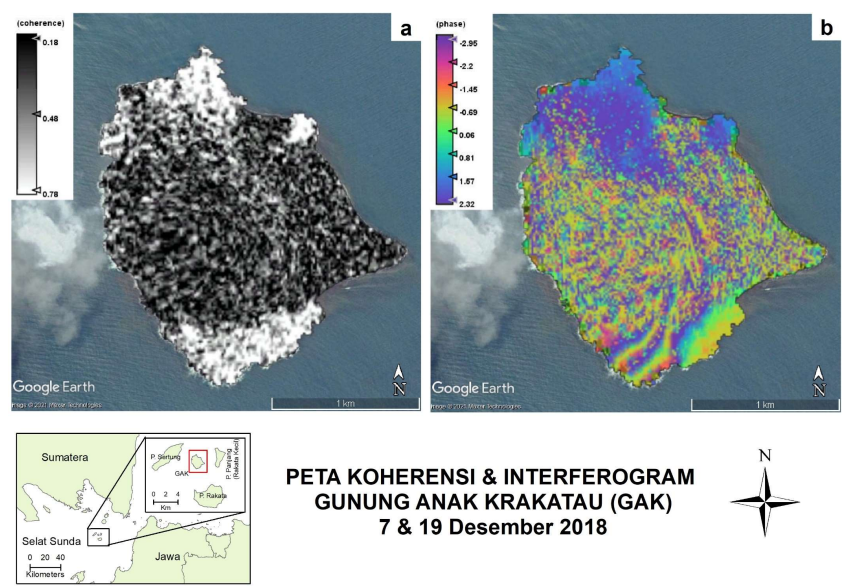

Gambar 5. Peta hasil pengolahan DInSAR yang menunjukkan nilai koherensi (a) dan interferogram (b) di GAK

backscatter-nya. Faktor rendahnya nilai koherensi dapat diakibatkan ketidakcocokan karakteristik sinyal dari dua sistem pencitraan sistem pencitraan sehingga timbul volume scattering error pada saat pemrosesan. Volume scattering mengurangi koherensi InSAR dan menambah noise pada fase interferometry. Nilai citra koherensi yang tinggi ditunjukkan dengan warna yang terang sedangkan koherensi rendah dengan warna gelap.

Berdasarkan hasil pengolahan interferogram GAK (Gambar 5b), terlihat pola deformasi yang ditunjukkan dengan munculnya fringes. Pola deformasi ini didominasi pada area erupsi, khususnya di kubah lava GAK ke arah dominan baratdaya. Pola fringes di bagian utara relatif satu warna dengan nilai koherensi tinggi, sehingga daerah ini diinterpretasikan sebagai area dengan deformasi sangat rendah. Sedangkan pada sisi timur dari puncak GAK, dengan nilai koherensi sangat rendah, merupakan efek dari vegetasi.

Untuk mendapatkan besaran nilai deformasi relatif terhadap Line of Sight (LOS), maka dilakukan proses Unwrapping (Gambar 6). Hasil Unwrapping $\Delta \varphi_{D-\text { Int }}$ menunjukkan nilai deformasi sebelum koreksi menunjukkan nilai 0 sampai dengan -1,566 m relatif terhadap LOS. Proses koreksi untuk mendapatkan $\varphi_{D}$ dilakukan sehingga diperoleh nilai deformasi LOS pada rentang $-0,12-0,04 \mathrm{~m}$. Hasil ini menunjukkan adanya deformasi negatif/menjauh dari sensor yang artinya terdapat pengurangan ketinggian/penurunan permukaan tanah (subsidence) di sekitar puncak GAK. Berkurangnya ketinggian/penurunan permukaan tanah ini disebabkan oleh adanya pergerakan massa dari puncak GAK relatif dominan ke arah baratdaya. Interpretasi ini juga terlihat pada deformasi positif yang terletak di lereng GAK sebelah barat dan selatan yang diperkirakan sebagai lokasi penumpukan material batuan yang longsor.

Meskipun hasil penelitian ini telah mampu mengidentifikasi adanya pergerakan massa di lereng GAK ke arah baratdaya, namun pergerakan ini belum mampu memicu terjadinya tsunami. Hal ini terbukti bahwa peristiwa tsunami justru terjadi tiga hari kemudian. Meskipun demikian, apakah pergerakan massa ini bisa digunakan untuk peringatan awal potensi tsunami di sekitar GAK tentunya masih membutuhkan kajian selanjutnya, mengingat saat ini kerucut GAK telah jauh berkurang.

Untuk mendapatkan gambaran yang lebih jauh terhadap deformasi yang terjadi pada periode sebelum tsunami ini (7 -19 Desember 2018), proses perhitungan luas dan volume telah dilakukan. Berdasarkan luasan GAK sebelum tsunami yang diperkirakan kurang lebih $180 \mathrm{Ha}$, maka dengan menggunakan persamaan 5 , luasan dan volume deformasi GAK dibagi menjadi tiga kelompok seperti yang ditunjukkan pada Gambar 7. Area deformasi tinggi ditandai dengan warna merah dengan luas relatif LOS sekitar 413.919,51 $\mathrm{m}^{2}$ atau $41 \mathrm{Ha}$. Sedangkan area deformasi sedang ditandai dengan warna oranye mencapai $500.906,83 \mathrm{~m}^{2}$ atau $50 \mathrm{Ha}$. Selanjutnya untuk area deformasi rendah ditandai dengan warna kuning mencapai 33.082,42 $\mathrm{m}^{2}$ atau 3 Ha. Dengan demikian total area deformasi GAK relatif terhadap LOS sekitar $94 \mathrm{Ha}$. 


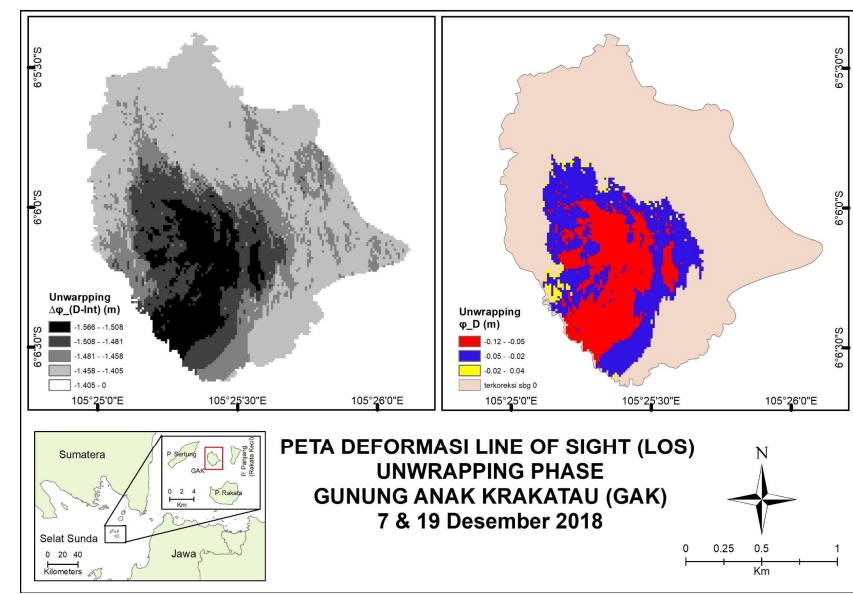

Gambar 7. Peta deformasi LOS hasil proses phase unwrapping GAK pada citra Sentinel-1 periode 7 \& 19 Desember 2018

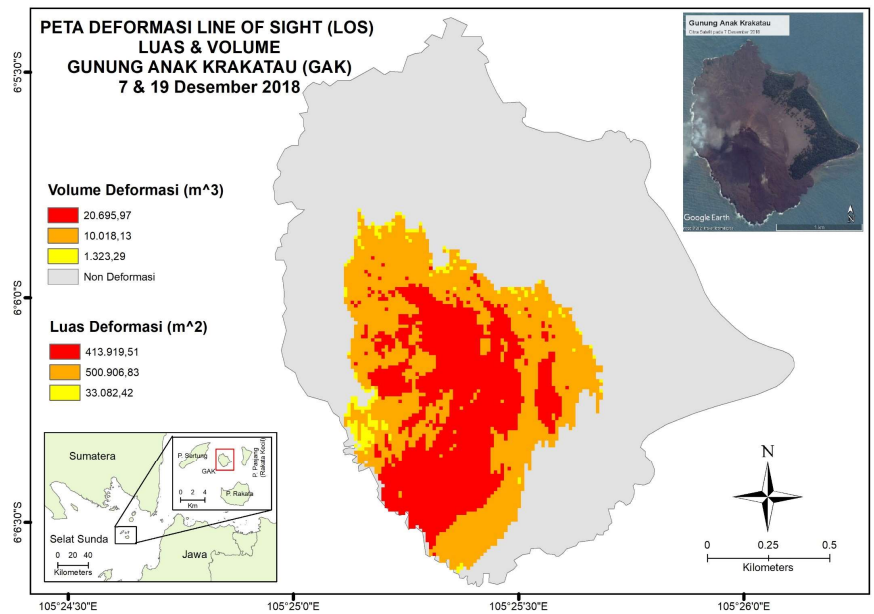

Gambar 6. Peta deformasi LOS yang menunjukkan luas area dan volume deformasi GAK periode 7 \& 19 Desember 2018

Berdasarkan hasil perhitungan yang ditunjukkan pada Gambar 7, total volume massa batuan yang bergerak pada periode 7 - 19 Desember 2018 di GAK mencapai sekitar $32.036 \mathrm{~m}^{3}$. Volume material yang cukup banyak ini tidak menghasilkan tsunami. Hal ini diperkirakan karena periode pergerakan tersebut terjadi secara perlahan dan tidak seketika yaitu pada rentang 12 hari. Hal ini juga terlihat bahwa material longsoran sebagian juga masih tertahan di lereng GAK khususnya di bagian barat. Kondisi ini mampu menjelaskan potensi material GAK yang menumpuk di lereng dekat permukaan laut yang apabila terjadi ketidakstabilan dan muncul peristiwa longsor secara serentak maka akan mampu memicu gelombang tsunami. Hipotesis penelitian ini memperkirakan bahwa setelah material longsoran tertumpuk dan menjadi tidak stabil, kemudian terjadi longsoran serentak yang kemungkinan dipicu oleh banyaknya aktivitas vulkanik GAK akhirnya memicu terjadinya tsunami pada 22 Desember 2018.

Pemanfaatan DInSAR pada penelitian ini telah terbukti mampu mengidentifikasi adanya pergerakan massa pada lereng GAK sebelum tsunami terjadi. Kemampuan ini merupakan suatu potensi yang cukup baik apabila dapat diterapkan dalam kegiatan pemantauan aktivitas vulkanisme gunung api khususnya yang berpotensi menimbulkan bencana. Terlebih lagi apabila dapat diaplikasikan dalam sistem peringatan dini di kawasan GAK dan Selat Sunda secara khusus.

\section{PENUTUP}

\section{Simpulan dan Saran}

Berdasarkan hasil pengolahan citra SAR Sentinel1 menggunakan metode DInSAR, penelitian ini berhasil mengidentifikasi adanya pergerakan 
massa berupa longsoran vulkanik pada periode 7 19 Desember 2018, yaitu tiga hari sebelum tsunami Selat Sunda. Peristiwa ini tidak memicu tsunami karena terjadi secara perlahan meskipun total area deformasi mencapai $94 \mathrm{Ha}$ dengan volume sekitar $32,036 \mathrm{~m}^{3}$ (relatif terhadap Line of Sight / LOS). Meskipun demikian, banyaknya material yang mulai bergerak dan tertahan di lereng GAK diperkirakan menjadi tidak stabil dan dapat bergerak secara serentak ke laut di bagian barat daya akibat banyaknya aktivitas vulkanik.

Penelitian ini mampu mengidentifikasi pergerakan massa di lereng GAK sebelum tsunami terjadi. Meskipun saat ini GAK telah banyak kehilangan material dan menjadi jauh lebih landai, pemantauan gerakan massa di GAK sangat penting dilakukan untuk memonitor potensi longsoran di masa yang akan datang. Pemanfaatan citra SAR sebagai bagian dari sistem peringatan dini perlu dipertimbangkan khususnya untuk pemantauan non-terestrial. Selanjutnya, untuk mengungkap dan membuktikan hipotesis penyebab tsunami yang disimpulkan pada penelitian ini, diperlukan penelitian lanjutan terkait dengan material longsoran mana yang menyebabkan tsunami Selat Sunda terjadi.

\section{Ucapan Terima Kasih}

Terima kasih kepada Alaska Satellite Facility (ASF) yang telah menyediakan data Sentinel-1, European Space Agency (ESA) yang menyediakan perangkat Sentinel Application Platform (SNAP). Terima kasih juga kepada LPPM Universitas Lampung, Jurusan Teknik Geofisika dan seluruh pihak yang telah membantu dalam menyelesaikan penelitian ini.

\section{DAFTAR PUSTAKA}

Abdurrachman, M., Widiyantoro, S., Priadi, B. dan Ismail, T. (2018), "Geochemistry and Structure of Krakatoa Volcano in the Sunda Strait, Indonesia", Geosciences, Vol.8, No.4, hal. 111. http://doi.org/10.3390/geosciences8040111.

Aji, R.P., Prasetyo, Y. dan Awaluddin, M. (2018), "Studi Sesar Lembang Menggunakan Citra Sentinel-1a untuk Pemantauan Potensi Bencana Gempa Bumi", Jurnal Geodesi Undip, Vol.7, No.4, hal. 304-313.
BMKG (2018), BMKG Ungkap Kronologi Tsunami Selat Sunda. Diambil dari https://www.bmkg.go.id/berita/?p=bmkg-ungkapkronologi-tsunami-selat-sunda\&tag=\&lang=ID.

Ckhotimah, H., Vonnisa, M. dan Budiman, A. (2020), "Pemanfaatan Data Alos PALSAR Untuk Etimasi Pergerakan Tanah Kota Padang Upaya Mitigasi Bencana Longsor", Jurnal Fisika Unand, Vol.9, No.1, hal. 93-99. http://doi.org/10.25077/jfu.9.1.9399.2020 .

Cyntia, I.P.P. (2018), "Analisis Penurunan Muka Tanah DKI Jakarta dengan Metode Differential Interferometry Synthetic Aperture Radar (DINSAR)", JIIF (Jurnal IImu dan Inovasi Fisika), Vol.2, No.2, hal. 88-99. http://doi.org/10.24198/jiif.v2i2.19712.

Deplus, C., Sylvain, B., Dahrin, D., Diament, M., Harjono, H. dan Dubois, J. (1995), "Inner structure of the Krakatau volcanic complex (Indonesia) from gravity and bathymetry data", Journal of Volcanology and Geothermal Research, Vol.64. http://doi.org/10.1016/0377-0273(94)00038-I.

Effendi, A.C., Sukhyar, R. dan Bronto, S. (1983), "Geology of Krakatau Complex", Proc. 100th year Develop. Krakatau and its surr, LIPI,.

Fauzi, A., Hunainah, dan Humaedi (2020), "Menyimak Fenomena Tsunami Selat Sunda", Jurnal Geografi dan Pengajarannya, Vol.18, No.1, hal. 43-62. http://doi.org/10.26740/jggp.v18n1.p43-62.

Febriyanti, R. dan Anjasmara, I. (2017), "Analisis Deformasi Gunung Raung Menggunakan Teknologi Differential Interferometry Synthetic Aperture Radar (DInSAR)", Jurnal Teknik ITS, Vol.6. http://doi.org/10.12962/j23373539.v6i2.25018.

Firdaus, M., Purnomo, J., Lukmana, A., Mokhamad, D. dan Cahyadi, N. (2016), Analisis Pengaruh Deformasi Muka Tanah terhadap Pembangunan di Daerah Pesisir dengan Teknik Differential Interferometric Synthetic Aperture Radar (DInSAR) (Studi Kasus: Pesisir Bangkalan, Madura) Analysis Influence of Deformation toward Development in Coastal Areas with Differential Interferometric Synthetic Aperture Radar (DInSAR) Technique (Case Study: Coastal Area Bangkalan, Madura),

Giachetti, T., Paris, R., Kelfoun, K. dan Ontowirjo, B. (2012), Tsunami Hazard Related to a Flank Collapse of Anak Krakatau Volcano, Sunda Strait, Indonesia, http://doi.org/10.1144/SP361.7.

Goldstein, R. dan Werner, C. (1998), "Radar Interferogram Filtering for Geophysical Applications. Geophysical Research Letters, 25, 4035-4038", Geophysical 
Research Letters,
http://doi.org/10.1029/1998GL900033.

Islam, L.J.F., Prasetyo, Y. dan Sudarsono, B. (2017), "Analisis Penurunan Muka Tanah (Land Subsidence) Kota Semarang Menggunakan Citra Sentinel-1 Berdasarkan Metode Dinsar pada Perangkat Lunak Snap", Jurnal Geodesi Undip, Vol.6, No.2, hal. 29-36.

Kurniawan, R. dan Anjasmara, I.M. (2016), "Pemanfaatan Metode Differential Intermerometry Synthetic Aperture Radar (DInSAR) untuk Pemantauan Deformasi Akibat Aktivitas Eksploitasi Panasbumi", Jurnal Teknik ITS, Vol.5, No.2, hal. B331-B336. http://doi.org/10.12962/j23373539.v5i2.17361.

Monterroso, F., Luca, C. de, Bonano, M., Lanari, R., Manunta, M., Manzo, M., Zinno, I. dan Casu, F. (2018), "Automatic Generation of Co-Seismic Displacement Maps by Using Sentinel-1 Interferometric SAR Data", Procedia Computer Science, Vol.138, hal. 332-337. http://doi.org/10.1016/j.procs.2018.10.047.

Muhari, A., Heidarzadeh, M., Susmoro, H., Nugroho, H.D., Kriswati, E., Supartoyo, Wijanarto, A.B., Imamura, F. dan Arikawa, T. (2019), "The December 2018 Anak Krakatau Volcano Tsunami as Inferred from PostTsunami Field Surveys and Spectral Analysis", Pure and Applied Geophysics, Vol.176, No.12, hal. 52195233. http://doi.org/10.1007/s00024-019-02358-2.

Nurtyawan, R. dan Utami, L.S. (2020), "Monitoring Deformasi Gunung Merapi Menggunakan Citra Sentinel-1A Dengan Menggunakan Metode DInSAR (Studi Kasus: Gunung Merapi, Jawa Tengah)", Rekayasa Hijau : Jurnal Teknologi Ramah Lingkungan, Vol.4, No.1, hal. 14-23. http://doi.org/10.26760/jrh.v4i1.14-23.

Paris, R., Switzer, A.D., Belousova, M., Belousov, A., Ontowirjo, B., Whelley, P.L. dan Ulvrova, M. (2014), "Volcanic Tsunami: A Review of Source Mechanisms, Past Events and Hazards in Southeast Asia (Indonesia, Philippines, Papua New Guinea)", Natural Hazards, Vol.70, No.1, hal. 447-470. http://doi.org/10.1007/s11069-013-0822-8.

Pratiwi, R., Prasetyo, Y. dan Yuwono, B.D. (2017), "Analisis Korelasi Deformasi dan Tutupan Lahan Kawasan Gunung Merapi Pra dan Pasca Erupsi", Jurnal Geodesi Undip, Vol.6, No.3, hal. 57-66.

Priyanto, W.S., Hunt, J.E., Hanif, M., Tappin, D.R., Permana, H., Susilohadi, Cassidy, M. dan Yulianto, E. (2021), "Bathymetry and Shallow Seismic Imaging of the 2018 Flank Collapse of Anak Krakatau", Frontiers in Earth Science, Vol.0. http://doi.org/10.3389/feart.2020.577448.
Putra, P.S., Aswan, A., Maryunani, K.A., Yulianto, E., Nugroho, S.H. dan Setiawan, V. (2020), "Post-Event Field Survey of the 22 December 2018 Anak Krakatau Tsunami", Pure and Applied Geophysics, Vol.177, No.6, hal. 2477-2492. http://doi.org/10.1007/s00024-020-02446-8.

Solihuddin, T., Salim, H.L., Husrin, S., Daulat, A. dan Purbani, D. (2020), "Dampak Tsunami Selat Sunda di Provinsi Banten dan Upaya Mitigasinya", Jurnal Segara, Vol.16, No.1, hal. 15-28. http://doi.org/10.15578/segara.v16i1.8611.

Sutawidjaja, I. (2006), "Pertumbuhan Gunung Api Anak Krakatau Setelah Letusan Katastrofis 1883", Indonesian Journal on Geoscience, Vol.1. http://doi.org/10.17014/ijog.vol1no3.20063.

Syamsidik, Benazir, Luthfi, M., Suppasri, A. dan Comfort, L.K. (2020), "The 22 December 2018 Mount Anak Krakatau Volcanogenic Tsunami on Sunda Strait Coasts, Indonesia: Tsunami and Damage Characteristics", Natural Hazards and Earth System Sciences, Vol.20, No.2, hal. 549-565. http://doi.org/10.5194/nhess-20-549-2020.

Walter, T.R., Haghshenas Haghighi, M., Schneider, F., Coppola, D., Motagh, M., Saul, J., Babeyko, A., Dahm, T., Troll, V., Tilmann, F., Heimann, S., Valade, S., Triyono, R., Khomarudin, R., Kartadinata, N., Laiolo, M., Massimetti, F. dan Gaebler, P. (2019), "Complex Hazard Cascade Culminating in the Anak Krakatau Sector Collapse", Nature Communications, Vol.10. http://doi.org/10.1038/s41467-019-12284-5.

Williams, R., Rowley, P. dan Garthwaite, M.C. (2019), "Reconstructing the Anak Krakatau Flank Collapse That Caused the December 2018 Indonesian Tsunami", Geology, Vol.47, No.10, hal. 973-976. http://doi.org/10.1130/G46517.1.

Ye, L., Kanamori, H., Rivera, L., Lay, T., Zhou, Y., Sianipar, D. dan Satake, K. (2020), "The 22 December 2018 Tsunami from Flank Collapse of Anak Krakatau Volcano During Eruption", Science Advances, Vol.6, No.3, hal. eaz1377. http://doi.org/10.1126/sciadv.aaz1377.

Yudhicara, Y. dan Budiono, K. (2014), "Tsunamigenik di Selat Sunda: Kajian terhadap katalog Tsunami Soloviev", Indonesian Journal on Geoscience, Vol.3. http://doi.org/10.17014/ijog.3.4.241-251.

Zen, M. dan Sudradjat (1983), "History of the Krakatau Volcanic Complex in Strait Sunda and the mitigation of its future hazards", Buletin Jurusan Geologi ITB,. 